\title{
Evaluasi Program Pembinaan Prestasi Cabang Olahraga Bola Voli Pantai
}

\author{
Johan Irmansyah \\ IKIP Mataram. Jalan Pemuda No. 59A Mataram, Indonesia. \\ Email: joevoley@gmail.com, Telp: (0370) 632082 \\ Received: 26 January 2017; Revised:3 April 2017; Accepted: 20 April 2017
}

\begin{abstract}
Abstrak
Penelitian ini bertujuan untuk mengevaluasi pelaksanaan program pembinaan prestasi cabang olahraga bola voli pantai di Provinsi Nusa Tenggara Barat (NTB) dan Daerah Istimewa Yogyakarta (DIY) dengan menggunakan model evaluasi CIPP (Contexs, Input, Process, Product). Penelitian ini merupakan penelitian evaluasi. Data dikumpulkan melalui observasi, wawancara, angket, dan dokumentasi. Teknik analisis data yang digunakan dalam penelitian ini yaitu análisis deskriptif kuantitatif dan kualitatif. Hasil penelitian menunjukkan bahwa secara keseluruhan hasil evaluasi program pembinaan prestasi cabang olahraga bola voli pantai di Provinsi NTB masih kurang baik dan di DIY sudah berjalan dengan baik. Pada evaluasi program pembinaan prestasi di NTB. Dari segi contexs sudah berjalan dengan baik. Dari segi input masih kurang baik. Dari segi process masih sangat kurang. Dari segi product secara garis besar prestasi yang diraih sudah baik, dapat dilihat dari hasil dokumentasi prestasi-prestasi yang pernah diraih oleh atlet-atlet NTB. Sedangkan di DIY, evaluasi program pembinaan prestasi dari segi contexs sudah berjalan dengan baik. Dari segi input sudah berjalan dengan baik. Dari segi process sudah berjalan dengan sangat baik. Dari segi product secara garis besar prestasi yang diraih sudah baik, dapat dilihat dari hasil dokumentasi prestasi-prestasi yang pernah diraih atlet-atlet DIY.
\end{abstract}

Kata Kunci: evaluasi program, pembinaan prestasi, dan bola voli pantai

\section{An Evaluation of Development Program of Beach Volleyball}

\begin{abstract}
This study was aimed to evaluate the implementation of sport development program of beach volleyball in the province of West Nusa Tenggara (NTB) and Special Region of Yogyakarta (DIY) by using the CIPP evaluation model (Contexs, Input, Process, Product). This study was an evaluation. The data were collected through observation, interviews, questionnaires, and documentation. Data analysis techniques used in this research was descriptive quantitative and qualitative analysis. The results show that the overall results of the evaluation of the achievements of sports coaching program of beach volleyball in the province of NTB are still not good and in DIY are good. At the evaluation of the coaching program achievement in the province of NTB, in terms of contexs, it has been running well. In terms of the input, it is still not good. In terms of process, it is still very poor. In terms of product in general, the achievement has been good, it can be seen from the accomplishment documentation that has ever been achieved by athletes of NTB. In DIY, the evaluation of the coaching program achievements in terms of contexs has been running well. In terms of input, it has been running well. In terms of process it is already under way with very good. In terms of product in general, the achievement has been good, it can be seen from the accomplishment documentation that has ever been achieved by DIY athletes.
\end{abstract}

Keywords: program evaluation, coaching achievement, and beach volleyball

How to Cite: Irmansyah, J. (2017). Evaluasi program pembinaan prestasi cabang olahraga bola voli pantai. Jurnal Keolahragaan, 5(1), 24-38. doi:http://dx.doi.org/10.21831/jk.v5i1.12759

Permalink/DOI: http://dx.doi.org/10.21831/jk.v5i1.12759 


\section{PENDAHULUAN}

Salah satu faktor pendukung tercapainya prestasi olahraga yang maksimal adalah dari pembinaan dan pembangunan olahraga itu sendiri. Untuk mencapai prestasi olahraga yang maksimal makin hari makin mendapatkan persaingan yang ketat baik dalam ruang lingkup nasional maupun internasional. Prestasi olahraga pada tingkat nasional dan internasional bukan lagi milik perseorangan, tetapi sudah menyangkut harkat dan kehormatan suatu bangsa. Untuk mencapai maksud tersebut, berbagai daya dan upaya dilakukan oleh suatu klub daerah, provinsi, dan nasional untuk menempatkan atletnya, baik pada tingkat daerah, nasional, atau event PON, Sea Games, Asean Games, dan Olimpiade.

Pembinaan dan pengembangan olahraga perlu terus ditingkatkan secara terarah, sistematis, dan berkesinambungan agar selaras dengan tujuan pembangunan nasional khususnya dalam meningkatkan kesejahteraan rakyat (Mutohir \& Maksum, 2007, p. 31).

Pembinaan olahraga prestasi ditujukan untuk kemajuan semua cabang olahraga yang ada di Indonesia, setiap cabang olahraga memiliki program pembinaan prestasi masing-masing baik dari tingkat daerah dan nasional. Tujuan utama dari program pembinaan prestasi adalah pembinaan atlet dari usia dini, pencarian bakatbakat atlet dalam setiap cabang olahraga dan mampu mencapai prestasi maksimal.

Pembinaan olahraga nasional dapat berjalan dengan sebaik-baiknya diperlukan komponen-komponen penting selain jalur-jalur pembinaan yang teridentifikasi. Komponen di dalam sistem pembinaan olahraga nasional adalah: (1) tujuan, (2) manajemen, (3) faktor ketenagaan, (4) atlet, (5) sarana dan prasarana, (6) struktur dan isi program, (7) sumber belajar, (8) metodologi, (9) evaluasi dan penelitian, serta (10) dana (Harsuki, 2012, p. 37).

Proses pembinaan yang sistematik, terencana, teratur dan berkesinambungan perlu dilakukan sebuah evaluasi karena suatu bidang pekerjaan dapat diketahui baik atau buruk jika telah dilakukan sebuah evaluasi. Suchman (Arikunto \& Jabar, 2009, p. 1) memandang evaluasi sebagai sebuah proses menentukan hasil yang telah dicapai beberapa kegiatan yang direncanakan untuk mendukung tercapainya tujuan.

Proses evaluasi harus dilaksanakan secara komprehensif agar hasilnya benar-benar dapat dijadikan dasar dalam menentukan kualitas dari suatu program, hal ini berarti evaluasi dijadikan secara menyeluruh untuk menilai unsur-unsur yang mendukung dari sebuah program. Sebuah program bukan hanya kegiatan tunggal yang dapat diselesaikan dalam waktu singkat, tetapi merupakan kegiatan yang berkesinambungan karena melaksanakan suatu kebijakan. Oleh karena itu, sebuah program dapat berlangsung dalam kurun waktu relatif lama. Pelaksanaan program selalu terjadi dalam sebuah organisasi yang artinya harus melibatkan sekelompok orang.

Pelaksanaan evaluasi program bertujuan untuk menemukan fakta-fakta pelaksanaan kebijakan publik di lapangan yang hasilnya bisa positif ataupun negatif. Sebuah evaluasi yang dilakukan secara profesional akan menghasilkan temuan yang objektif yaitu temuan apa adanya: baik data, analisis, dan kesimpulannya tidak dimanipulasi yang akhirnya akan memberikan manfaat kepada semua orang yang bersangkutan dalam program pembinaan itu.

Voli pantai adalah variasi dari bola voli yang dimainkan di atas pasir. Voli pantai populer sebagai aktivitas rekreasi di tempat-tempat yang memiliki pantai berpasir yang luas, namun sering juga dimainkan di lapangan pasir dan bukan di pantai. Di NTB dan DIY voli pantai belum terlalu populer jika dibandingkan dengan voli indoor, pemasalan yang kurang membuat cabang olahraga voli pantai sangat susah merekrut atlet yang berbakat. Fenomena ini berbanding terbalik dengan prestasi yang telat diraih oleh atlet voli pantai jika dibandingkan dengan atlet voli indoor. Dapat dilihat secara umum dalam sepuluh tahun terakhir ini, NTB dan DIY membuktikan dengan peraihan medali di ajang event olahraga terbesar di Indonesia yaitu PON (Pekan Olahraga Nasional). Pembinaan atlet berprestasi dalam cabang olahraga voli pantai di NTB dan DIY tidak lepas dari sistem kepengurusan dari provinsi masing-masing dan di bawah naungan dari PBVSI NTB dan DIY. Lahirnya atlet-atlet berbakat harus melalui proses yang sangat panjang, seleksi atlet sejak usia dini dan sistem pembinaan yang terorganisasi dengan baik.

Berikut akan dijelaskan hasil peraihan medali dalam PON tahun 2000-2012 cabang olahraga voli pantai di NTB dan DIY. 
Tabel 1. Data Prestasi Atlet Voli Pantai Putra DIY yang telah Diraih dalam PON

\begin{tabular}{ccc}
\hline No. & Tahun PON & Prestasi yang Diraih \\
\hline 1. & PON 2000 & - \\
2. & PON 2004 & Juara 1 medali emas \\
3. & PON 2008 & Juara 1 medali emas \\
4. & PON 2012 & Juara 1 medali emas \\
\hline
\end{tabular}

Tabel 2. Data Prestasi Atlet Voli Pantai Putri DIY yang telah Diraih dalam PON

\begin{tabular}{ccc}
\hline No. & Tahun PON & Prestasi yang Diraih \\
\hline 1. & PON 2000 & - \\
2. & PON 2004 & - \\
3. & PON 2008 & - \\
4. & PON 2012 & - \\
\hline
\end{tabular}

Tabel 3. Data Prestasi Atlet Voli Pantai Putra NTB yang telah Diraih dalam PON

\begin{tabular}{ccc}
\hline No. & Tahun PON & Prestasi yang Diraih \\
\hline 1. & PON 2000 & Juara 2 medali perak \\
2. & PON 2004 & Masuk 4 besar \\
3. & PON 2008 & Masuk 8 besar \\
4. & PON 2012 & - \\
\hline
\end{tabular}

Tabel 4. Data Prestasi Atlet Voli Pantai Putri NTB yang telah Diraih dalam PON

\begin{tabular}{ccc}
\hline No. & Tahun PON & Prestasi yang Diraih \\
\hline 1. & PON 2000 & Juara 3 perunggu \\
2. & PON 2004 & Juara 1 medali emas \\
3. & PON 2008 & - \\
4. & PON 2012 & Juara 1 medali emas \\
\hline
\end{tabular}
data prestasi yang telah diraih, atlet voli pantai DIY dan NTB memiliki perbedaan. Atlet putra maupun putri memiliki kelebihan dan kekurangan masing-masing. Hasil maksimal yang telah diraih oleh NTB dan DIY ternyata masih ada masalah-masalah internal maupun eksternal dalam sistem pembinaan cabang olahraga voli pantai ini. Dapat dibuktikan dengan hasil peraihan PON terebut, dalam penelitian ini akan dibahas secara lebih spesifik lagi tentang program pembinaan prestasi cabang olahraga voli pantai yang digunakan Provinsi NTB dan DIY. Oleh karena itu, peningkatan dan pengembangan sistem pembinaan atlet berprestasi mempunyai suatu sasaran yang ingin dicapai, baik dalam visi misi maupun perencanaan strategis jangka pendek, jangka menengah, maupun jangka panjang. Melalui pengukuran sesuai prosedur, akan dapat dievaluasi secara bertahap dan berkelanjutan segala program yang terkait dengan pembinaan olahraga. Adapun pihak-pihak yang sangat memengaruhi terhadap hal tersebut antara lain meliputi pembina olahraga (pelatih, pengurus induk organisasi keolahragaan seperti KONI,
PBVSI, Pengda, Pengcab klub, dan Pengprov), atlet, dan masyarakat sekitar.

Evaluasi dalam penelitian ini akan menggunakan Model CIPP karena Model CIPP adalah evaluasi yang dilakukan secara kompleks yang meliputi Context, Input, Process, dan Product. Model CIPP dipandang sebagai satu model evaluasi yang sangat komprehensif. Model CIPP adalah model evaluasi yang memberikan manfaat untuk melihat apakah program telah berjalan sesuai dengan yang direncana$\mathrm{kan} /$ diinginkan dan menghasilkan product sesuai dengan yang direncanakan. Pada model CIPP pelaku evaluasi biasanya tidak berhubungan langsung dengan program yang akan dievaluasi, akan tetapi dapat bekerja dengan salah seorang yang terlihat langsung dalam program tersebut. Selain itu, pelaku evaluasi harus dapat bekerja sama dengan orang-orang yang bekerja sebagai staf dalam pelaksanaan program, hal ini perlu dilakukan agar pelaku evaluasi dapat menentukan dan mendaptakan segala informasi dan juga untuk interpretasi data yang akan digunakan untuk pengambilan keputusan. Model CIPP akan maksimal pelaksanaannya jika ada kerja sama yang baik antara pelaku evaluasi dengan pelaksana sebuah program.

Evaluasi ini bertujuan untuk memberikan gambaran hasil dari program pembinaan prestasi tersebut dengan harapan dapat membantu pelatih, atlet, dan pemerintah daerah agar bisa mempertahankan dan mengoptimalkan lagi prestasi atlet untuk mencapai level yang lebih tinggi lagi. Ini sebagai bahan acuan untuk pengurus PBVSI provinsi Nusa Tenggara Barat dan Daerah Istimewa Yogyakarta agar dapat lebih memperhatikan pembinaan prestasi olahraga bola voli pantai dan semua aspek yang menunjang prestasi atlet dan juga sebagai referensi untuk lebih memajukan prestasi olahraga di Indonesia khususnya voli pantai.

\section{METODE}

Penelitian ini adalah penelitian evaluasi yang menggunakan metode campuran kuantitatif dan kualitatif. Farquhar, Ewing, \& Booth (2011, p. 749) menyatakan di antara banyak definisi tentang metode campuran, beberapa sangat cocok untuk pengembangan dan evaluasi dari intervensi yang kompleks, yaitu orang menangkap tentang pembelajaran individu dan program pembelajaran yang terkait. Metode campuran seperti menggabungkan pendekatan kualitatif dan kuantitatif ke dalam metodologi penelitian. 
Sugiyono (2004, p. 404) menyatakan bahwa metode penelitian kombinasi adalah suatu metode penelitian yang mengombinasikan atau menggabungkan antara metode kuantitatif dan metode kualitatif untuk digunakan secara bersama-sama dalam suatu kegiatan penelitian, sehingga diperoleh data yang lebih komprehensif, valid, reliabel, dan objektif.

Berdasarkan pendapat tersebut, metode kombinasi merupakan metode yang menggunakan data kualitatif dan kuantitaif. Diharapkan penggunaan metode kombinasi dalam penelitian ini mampu mendapatkan data yang benar-benar nyata sesuai dengan kondisi program pembinaan prestasi di DIY dan NTB.

Model evaluasi yang akan digunakan dalam peneltian ini adalah model CIPP karena model CIPP adalah evaluasi yang dilakukan secara kompleks yang meliputi context, input, process, dan product. Model CIPP dipandang sebagai salah satu model evaluasi yang sangat komprehensif.

Berdasarkan berbagai model evaluasi yang ada, model CIPP adalah model evaluasi yang memberikan manfaat untuk melihat apakah program telah berjalan sesuai dengan yang direncanakan/diinginkan dan menghasilkan product sesuai dengan yang direncanakan. Pada model CIPP pelaku evaluasi biasanya tidak berhubungan langsung dengan program yang akan dievaluasi, akan tetapi dapat bekerja dengan salah seorang yang terlibat langsung dalam program tersebut. Selain itu, pelaku evaluasi harus dapat bekerja sama dengan orang-orang yang bekerja sebagai staf dalam pelaksanaan program, hal ini perlu dilakukan agar pelaku evaluasi dapat menentukan dan mendaptakan segala informasi dan juga untuk interpretasi data yang akan digunakan untuk pengambilan keputusan. Model CIPP akan maksimal pelaksanaannya jika ada kerja sama yang baik antara pelaku evaluasi dan pelaksana sebuah program.

Penelitian ini dilakukan di Provinsi Nusa Tenggara Barat pada klub AS-VTC (Agus Salim Volleyball Training Center) dan Daerah Istimewa Yogyakarta pada klub GANEVO, pada bulan Februari-April 2015.

Subjek penelitian ini adalah pengurus PBVSI NTB dan DIY, pelatih, atlet, dan orang tua atlet. Dari subjek yang diteliti harus dapat menghasilkan gambaran yang reliabel atau dapat dipercaya. Dalam hal ini subjek yang dipilih haruslah betul-betul merepresentasikan keadaan yang sesungguhnya, oleh karena itu pemilihan subjek yang ideal dapat menentukan ketepatan hasil penelitian dan memperolah data yang sebenarnya sesuai dengan tujuan dari penelitian ini.

Sumber data dalam penelitian ini adalah atlet, pelatih, orang tua atlet, pengurus PBVSI NTB dan DIY, pengurus KONI dalam bidang pembinaan prestasi yang berjumlah 59 orang yang terdiri atas 34 orang subjek penelitian DIY dan 25 orang subjek penelitian NTB. Semua subjek dalam penelitian ini adalah subjek yang dianggap mengetahui tentang program pembinaan prestasi yang ada di provinsi masing-masing.

Metode pengumpulan data merupakan suatu hal yang penting dalam penelitian, karena metode ini merupakan strategi atau cara yang digunakan oleh peneliti untuk mengumpulkan data yang diperlukan dalam penelitiannya. Pengumpulan data dalam penelitian dimaksudkan untuk memperoleh bahan-bahan, keterangan, kenyataan-kenyataan, dan informasi yang dapat dipercaya (Widoyoko, 2012, p. 33).

Instrumen adalah alat ukur yang digunakan dalam penelitian. Instrumen penelitian adalah suatu alat yang digunakan untuk mengukur fenomena alam maupun sosial yang diamati. Secara spesifik semua fenomena ini disebut variabel penelitian (Sugiyono, 2004, p. 148). Dalam penelitian ini instrumen yang digunakan adalah angket, wawancara, pedoman observasi dan dokumentasi.

Dalam penelitian ini, instrumen berupa angket dan pedoman wawancara baik yang ditujukan pada pelatih, atlet, pengurus PBVSI NTB dan DIY, dan orangtua atlet dibuat sendiri oleh peneliti. Sebelum digunakan untuk mengumpulkan data di lapangan, angket dan pedoman wawancara tersebut perlu diujicobakan, dibuktikan validitas dan reliabilitasnya.

Instrumen dikatakan valid apabila instrumen tersebut dapat dengan tepat mengukur apa yang hendak diukur. Dengan kata lain validitas berkaitan dengan "ketepatan" dengan alat ukur. Dengan instrumen yang valid akan dihasilkan data yang valid pula atau dapat juga dikatakan bahwa jika data yang dihasilkan dari sebuah instrumen valid, instrumen itu juga valid (Widoyoko, 2012, p. 142). Validitas isi terhadap angket dan pedoman wawancara di dalam penelitian evaluasi ini telah ditempuh dengan cara mengembangkan instrumen melalui kisi-kisi yang disusun berdasarkan kajian teori. Kajian teori prosesnya dilakukan penelaahan secara cermat oleh peneliti dengan pengarahan dosen pembimbing dan validator (expert judgement). Pada instrumen angket harus dilakukan 
analisis/uji coba terhadap validitas butir angket, hal ini dilakukan untuk mengetahui kesahihan setiap butir dalam angket tersebut.

Widoyoko (2012, p. 147) menyatakan bahwa suatu butir instrumen dikatakan valid apabila memiliki sumbangan yang besar terhadap skor total. Dengan kata lain dikatakan mempunyai validitas yang tinggi jika skor pada butir mempunyai kesejajaran dengan skor total. Kesejajaran ini dapat diartikan dengan korelasi, sehingga untuk mengetahui validitas butir digunakan rumus korelasi product moment. Perhitungan validitas butir soal juga bisa dilakukan dengan bantuan komputer (SPSS Version 22).

Suatu instrumen dikatakan dapat dipercaya atau reliable apabila digunakan dapat menghasilkan data yang benar, tidak menyimpang atau tidak berbeda dari kenyataan. Rumus untuk mengukur reliabilitas instrumen yaitu dengan rumus Alpha (Arikunto \& Jabar, 2009, p. 239).

$$
r_{11}=\left(\frac{\mathrm{k}}{k-1}\right)\left(1-\frac{\sum \alpha b^{2}}{\alpha_{t}^{2}}\right)
$$

Keterangan:

$r_{11}:$ reliabilitas instrumen

$\mathrm{k}$ : banyaknya butir pertanyaan atau banyaknya soal

$\sum \sigma b^{2}:$ jumlah varians butir

$\sigma_{1}^{2}$ : varians total

Hasil uji coba instrumen menunjukkan semua butir soal valid karena $\mathrm{r}$ hitung $>\mathrm{r}$ tabel, sedangkan hasil uji reliabilitas sebesar 0,946 lebih besar dari 0,6 sehingga dikatakan reliabel dalam kategori tinggi.

Teknik analisis data yang digunakan dalam penelitian evaluasi ini adalah analisis deskriptif kuantitatif dan kualitatif, dengan mendeskripsikan dan memaknai data dari tiap-tiap komponen yang dievaluasi baik data kuantitatif maupun data kualitatif. Data dari instrumen angket dianalisis dengan cara kuantitatif dan data dari hasil wawancara akan dianalisis secara kualitatif.

\section{HASIL DAN PEMBAHASAN}

\section{Deskripsi Hasil}

Penelitan evaluasi program pembinaan prestasi voli pantai di DIY dan NTB ini menghasilkan fakta-fakta tentang permasalahan-permasalahan yang ada dalam suatu program pembinaan. Semua data yang akan dijelaskan dalam evaluasi ini merupakan data sesungguh- nya dari hasil evaluasi yang telah dilakukan oleh peneliti. Banyak temuan yang positif maupun negatif yang didapatkan peneliti selama melakukan evaluasi di DIY dan NTB, temuantemuan tersebut di antaranya: (1) perbedaan program pembinaan yang sangat signifikan antara DIY dan NTB, DIY memiliki program pembinaan yang sudah berjalan dengan baik sedangkan di NTB masih belum berjalan dengan baik, (2) sarana dan prasarana yang masih kurang memadai di NTB jika dibandingkan dengan DIY, (3) permasalahan pendanaan yang tidak terprogram dengan baik di NTB, (4) proses program pembinaan dan monev (monitoring \& evaluasi) di NTB masih sangat kurang jika dibandingkan dengan DIY.

\section{Hasil Analisis}

Data Uji Coba Angket

Sebelum melakukan analisis terhadap hasil penelitian, akan dibahas pertama kali hasil uji coba/validitas butir angket yang telah dilakukan sebelum turun langsung ke lapangan/ tempat penelitian. Dari hasil uji coba angket terdapat beberapa butir soal yang gugur. Widoyoko (2012, p. 146) menyatakan bahwa uji coba di lapangan harus dilakukan karena hal ini untuk mengetahui validitas faktor maupun validitas butir instrumen. Tidak menutup kemungkinan secara konstruk teoretis instrumen sudah valid karena sudah disusun berdasarkan teori variabel yang akan diukur, dilanjutkan dengan perumusan definisi operasional, indikator, dan penyusunan butir-butir. Setelah diujicobakan di antara faktor-faktor maupun butir-butir instrumen ada yang tidak valid sehingga mengurangi validitas instrumen secara keseluruhan. Sampel uji coba minimal 30 orang.

Uji coba instrumen dilaksanakan pada tanggal 1-10 Februari 2015 dengan menyebar angket ke tiga puluh responden. Responden dalam uji coba ini adalah tim voli pantai Kabupaten Lombok Tengah yang dilakukan secara acak (random sampling). Semua responden uji coba memiliki karakter yang sama dengan subjek penelitian.

\section{Uji Validitas Butir Angket}

Penelitian ini memiliki empat model angket yaitu; angket untuk pengurus PBVSI, angket untuk pelatih, angket untuk atlet, dan angket untuk orangtua. Meskipun demikian, angket yang akan diuji untuk validitas butir 
hanya tiga model yaitu pengurus PBVSI, pelatih, dan atlet.

Angket untuk orang tua tidak diuji karena dalam hal ini butir pernyataan dalam angket orang tua hanya empat belas butir, dan data yang didapat dari angket orang tua digunakan sebagai data pendukung dalam penelitian.

\section{Hasil Analisis Data}

Data mengenai hasil penelitian akan dibahas secara detail sesuai dengan provinsi masingmasing dan sistematika dari model evaluasi yang digunakan. Dalam hal ini yang akan dilakukan adalah menjelaskan data hasil analisis kuantitatif dan kualitatif dari semua aspek yang digunakan dalam penelitian dan semua faktor yang mendukung untuk menghasilkan data penelitian yang sebenarnya/sesungguhnya.

\section{Analisis Data di DIY}

Penjelasan berikut ini akan membahas evaluasi program pembinaan prestasi ditinjau dari segi contexs, input, process dan product serta setiap aspek yang diungkap dalam penelitian program pembinaan prestasi di DIY.

Evaluasi contexs menurut Arikunto \& Jabar (2009, p. 46) adalah upaya untuk menggambarkan dan merinci lingkungan, kebutuhan yang tidak terpenuhi, populasi dan sampel yang dilayani, dan tujuan proyek. Dalam hal ini terdapat beberapa aspek yang digunakan dalam evaluasi contexs. Berikut hasil analisis kuantitatif dari aspek-aspek yang terdapat dalam evaluasi contexs.

Evaluasi input (masukan) adalah kemampuan awal suatu keadaan dalam menunjang suatu program, Stufflebeam (Worthen, Sanders, \& Fitzpatrick, 2004, p. 89) menyatakan bahwa:

Input evaluations, to serve structuring decisions: after defining needs and considering organizational assets and potential interventions, using input evaluation help managers to select a particular strategy to implement and to resolve the problem and make decisions about how to implement it.

Evaluasi masukan menilai pendekatan alternatif, kegiatan rencana, rencana kepegawaian, dan anggaran untuk kelayakan dan potensi efektivitas biaya untuk memenuhi kebutuhan dan mencapai tujuan yang ditargetkan. Kaitannya dengan penelitian ini, evaluasi input adalah kegiatan untuk menganalisis sumber daya dalam hal ini adalah atlet, pelatih, dan juga pendukung lainnya seperti dana, sarana-prasarana yang dibutuhkan untuk mencapai tujuan program tersebut.

Tabel 5. Hasil Evaluasi Contexs DIY

\begin{tabular}{lccl}
\hline \multicolumn{1}{c}{ Cspek } & & \multicolumn{1}{c}{ Pencapaian } \\
\hline \multicolumn{1}{c}{ Contexs } & Rata-rata & Kategori & \multicolumn{1}{c}{ Keterangan } \\
\hline Latar Belakang Program Pembinaan & 3.142 & Baik & Sudah berjalan dengan baik \\
Tujuan Program Pembinaan & 3.263 & Baik & Sudah tercapai sesuai dengan tujuan yang telah \\
Program Pembinaan & 3.263 & Baik & Sudah berjalan dengan baik \\
\hline
\end{tabular}

(Sumber Data: Angket, Wawancara, Observasi, dan Dokumentasi)

Tabel 6. Hasil Evaluasi Input DIY

\begin{tabular}{|c|c|c|c|}
\hline \multirow{2}{*}{$\begin{array}{l}\text { Aspek } \\
\text { Input }\end{array}$} & \multicolumn{3}{|r|}{ Pencapaian } \\
\hline & Rata-rata & Kategori & Keterangan \\
\hline Pelatih & 3.226 & Baik & $\begin{array}{l}\text { Kualitas pelatih sudah baik dengan pengalamannya sebagai mantan } \\
\text { atlet dan sertifikat kepelatihan }\end{array}$ \\
\hline Atlet & 3.158 & Baik & Pemassalan dan Rekruitmen atlet sudah berjalan dengan baik \\
\hline $\begin{array}{c}\text { Sarana dan } \\
\text { Prasarana }\end{array}$ & 3.147 & Baik & $\begin{array}{l}\text { Sarana dan Prasarana sudah memadai sesuai dengan data observasi dan } \\
\text { dokumentasi yang diambil di lapangan }\end{array}$ \\
\hline Pendanaan & 3.168 & Baik & Pendanaan sudah disalurkan sesuai dengan program dan kebutuhan \\
\hline $\begin{array}{l}\text { Dukungan } \\
\text { Orang Tua }\end{array}$ & 3.379 & $\begin{array}{c}\text { Sangat } \\
\text { baik }\end{array}$ & $\begin{array}{l}\text { Dukungan yang sangat positif dari semua orang tua atlet untuk } \\
\text { kemajuan voli pantai DIY }\end{array}$ \\
\hline
\end{tabular}

(Sumber Data: Wawancara, Angket, Observasi, dan Dokumentasi) 
Jurnal Keolahragaan 5 (1), April 2017 - 30

Johan Irmansyah

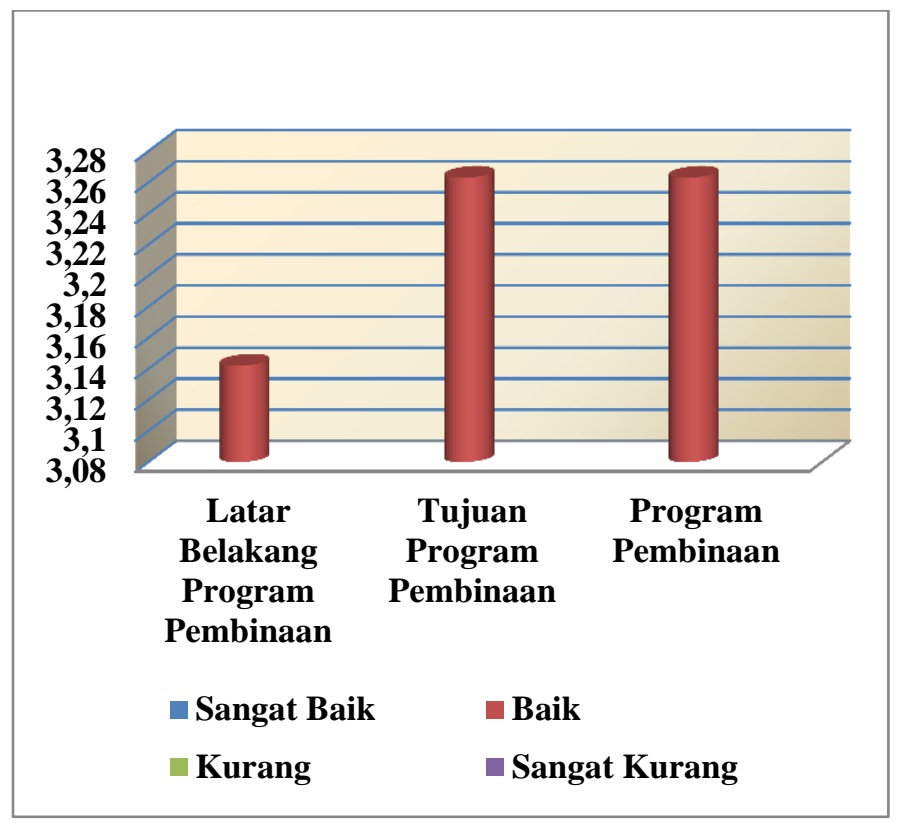

Gambar 1. Histogram Evaluasi Contexs DIY

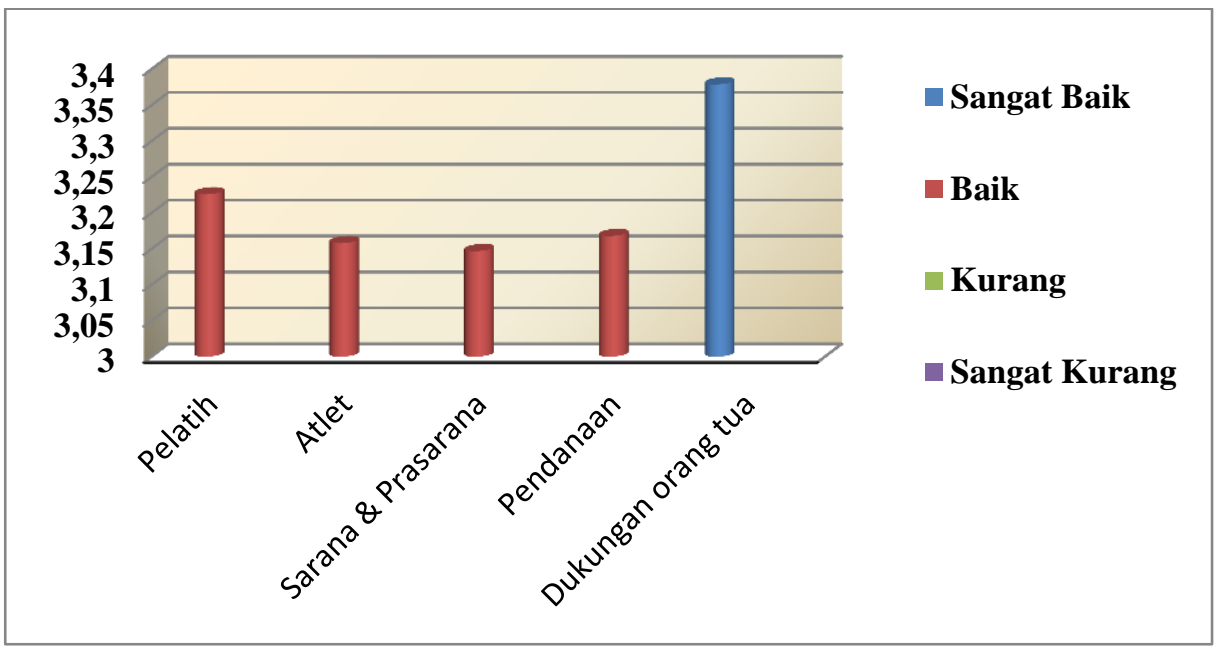

Gambar 2. Histogram Evaluasi Input DIY

Berdasarkan data dari Tabel 6, dapat disimpulkan bahwa semua aspek yang diungkap telah terlaksana dengan baik. Sesuai dengan data yang didapat peneliti di lapangan, baik dalam bentuk wawancara, angket, observasi maupun dokumentasi, DIY memang salah satu provinsi yang memiliki program pembinaan voli pantai yang baik. Semua sudah terlaksana sesuai dengan sistematika yang telah disusun oleh pengurus DIY. Hal ini dapat dilihat dari program pembinaan yang telah dilaksanakan dari usia dini dan beasiswa untuk atlet-atlet yang berbakat serta dukungan dana maupun dukungan morel dari pemprov, pelatih dan orangtua. Semua telah bersinergi untuk terus saling mendukung demi kemajuan voli pantai DIY.

Evaluasi process sebagai bahan untuk mengimplementasikan suatu keputusan yang akan diambil, dalam hal ini akan dilihat tepat tidaknya pelaksanaan suatu program yang telah ditetapkan. Arikunto \& Jabar (2009, p. 47) mengemukakan evaluasi process diarahkan pada seberapa jauh kegiatan yang dilaksanakan di dalam program sudah terlaksana sesuai dengan rencana.

Selanjutnya Stufflebeam (Worthen et al., 2004, p. 89) mengemukakan:

Process evaluation, to serve implementing decisions: once the programs have begun, the important decisions concern how to modify its implementation. Key evaluation questions are: is the program being implemented as planned? What change has been made? What barriers threaten its success? What revisions are needed? As 
these questions are answered, procedures can be monitored, adapted, and refined.

Evaluasi process menilai pelaksanaan rencana untuk membantu staf melakukan kegiatan dan kemudian membantu kelompok lebih luas dari kinerja suatu program dan menginterpretasikan hasil. Hubungan evaluasi process dalam sebuah program, akan dapat menjawab pertanyaan, apakah kegiatan program telah sesuai dengan plot waktu yang dijadwalkan, apakah kemampuan sumber daya manusia (pelaksana program) sudah sesuai dengan kriteria yang ditetapkan, apakah sarana dan prasarana yang tersedia sudah dimanfaatkan dengan baik dan kendala-kendala yang ditemukan selama pelaksanaan program.

Proses dalam evaluasi ini mencakup aspek-aspek tentang berjalannya pelaksanaan program latihan, pelaksanaan program pembinaan dan monev dari pengurus PBVSI.

Berdasarkan data dari Tabel 7, dapat disimpulkan bahwa semua aspek yang diungkap dalam evaluasi process sudah berjalan dengan baik. DIY merupakan salah satu provinsi yang memiliki program pembinaan yang telah tersusun secara sistematis, dan pelaksanaanya juga sudah sesuai dengan yang telah diprogramkan.

Evaluasi product merupakan tahap akhir dari serangkaian evaluasi program. Arikunto \& Jabar (2009, p. 47) menyatakan bahwa evaluasi product atau hasil diarahkan pada hal-hal yang menunjukkan perubahan yang terjadi pada masukan mentah.

Menurut (Gall, Gall, \& Borg, 2007, p. 580),

Product evaluation involves determining the extent to which the goals of the program have been achieved. In this type of evaluation, measures of the goals are developed and administered, and the resulting data are used to make decisions about continuing or modifying the program.

Evaluasi product menentukan sejauh mana tujuan program telah tercapai. Dalam jenis evaluasi, langkah-langkah tujuan yang dikembangkan dan dikelola, dan data yang dihasilkan digunakan untuk membuat keputusan tentang melanjutkan atau memodifikasi program.

Evaluasi product membahas tentang prestasi yang telah diraih atlet, baik dari tingkat daerah sampai ke tingkat internasional. Prestasi merupakan tolok ukur keberhasilan suatu program pembinaan yang telah dijalankan oleh tiaptiap provinsi, semakin banyak prestasi yang dicapai, akan semakin baik program pembinaannya. Prestasi juga merupakan kebanggaan bagi semua pihak yang terhubung di dalamnya dan semua aspek yang mendukung keberhasilan pencapain prestasi tersebut.

Tabel 7. Hasil Evaluasi Process DIY

\begin{tabular}{|c|c|c|c|}
\hline Aspek & & & Pencapaian \\
\hline Process & Rata-rata & Kategori & Keterangan \\
\hline Pelaksanaan Program Latihan & 3.151 & Baik & Sudah berjalan sesuai dengan program yang ada \\
\hline $\begin{array}{l}\text { Pelaksanaan Program } \\
\text { Pembinaan }\end{array}$ & 3.183 & Baik & $\begin{array}{l}\text { Sudah berjalan sesuai dengan prosedur program } \\
\text { pembinaan yang ada, baik dari program usia } \\
\text { dini, pemanduan bakat, dan program prestasi }\end{array}$ \\
\hline Monev & 3.443 & Sangat baik & $\begin{array}{l}\text { Perhatian pemprov sangat baik untuk kemajuan } \\
\text { voli pantai DIY. }\end{array}$ \\
\hline
\end{tabular}

(Sunber Data: Wawancara, Angket, Observasi, dan Dokumentasi)

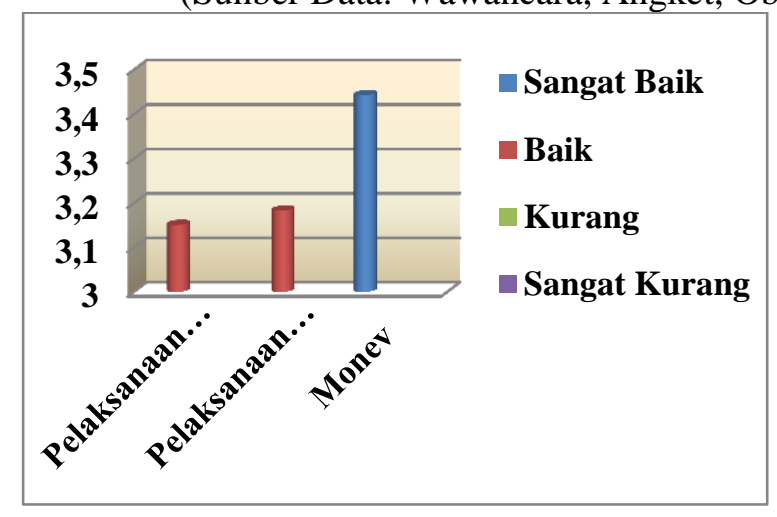

Gambar 3. Histogram Evaluasi Process DIY 
Jurnal Keolahragaan 5 (1), April 2017 - 32

Johan Irmansyah

Tabel 8. Hasil Evaluasi Product DIY

\begin{tabular}{|c|c|c|c|}
\hline Aspek & \multicolumn{3}{|c|}{ Pencapaian } \\
\hline Product & Rata-rata & Kategori & Keterangan \\
\hline PRESTASI & 3.153 & Baik & $\begin{array}{l}\text { Hasil prestasi } \\
\text { atlet sudah } \\
\text { baik, bisa } \\
\text { dilihat dalam } \\
\text { tabel } \\
\text { lampiran }\end{array}$ \\
\hline \multicolumn{4}{|c|}{ (Sumber Data: Angket dan Dokumentasi) } \\
\hline 4 & & \multirow{4}{*}{\multicolumn{2}{|c|}{$\begin{array}{l}\text { Sangat Baik } \\
\text { Baik } \\
\text { Kurang } \\
\text { Sangat Kurang }\end{array}$}} \\
\hline 3 & & & \\
\hline 2 & & & \\
\hline 1 & & & \\
\hline \multicolumn{4}{|c|}{ Prestasi } \\
\hline
\end{tabular}

Gambar 4. Histogram Evaluasi Product DIY

Berdasarkan data Tabel 8, dapat dibuktikan bahwa DIY merupakan salah satu penghasil atlet-atlet berbakat yang mampu berprestasi sampai tingkat nasional maupun international. Sejak PON tahun 2000 DIY selalu mampu menghasilkan atlet-atlet berprestasi, semua itu dikarenakan proses latihan yang keras dan professional serta dukungan penuh dari pemerintah daerah maupun pemprov.

\section{Analisis Data NTB}

Pembahasan aspek-aspek yang terdapat dalam evalusai contexs berikut ini diambil dari beberapa responden yang telah diteliti dengan metode, wawancara/data kualitatif, angket, observasi dan dokumentasi. Semua pembahasan atau data yang ada dalam evaluasi contexs ini memiliki keaslian karena peneliti turun langsung ke lapangan untuk mendapatkan data yang sesungguhnya.
Tabel 9. Hasil Evaluasi Contexs NTB

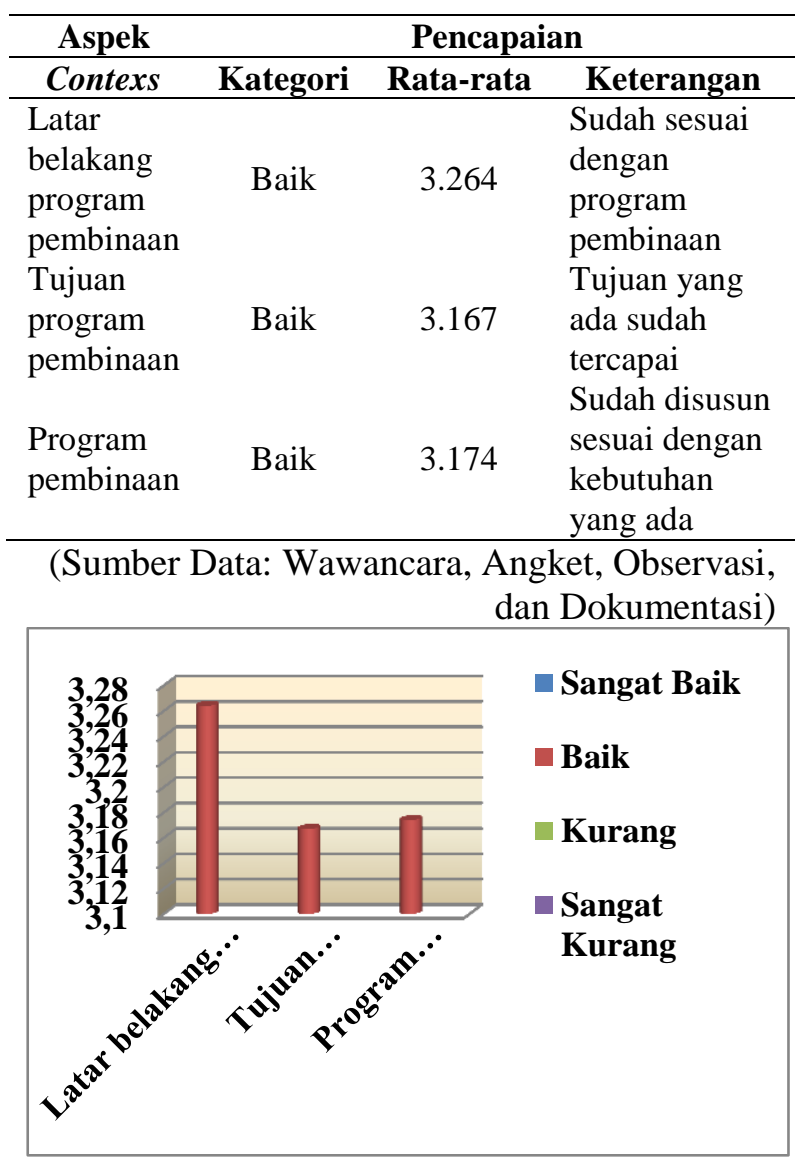

Gambar 5. Histogram Evaluasi Contexs NTB

Berdasarkan Tabel 9, banyak masukan dan saran dari tiap-tiap responden, akan tetapi dari semua data yang telah diambil baik berupa angket, observasi dan wawancara, program pembinaan yang ada di NTB sudah tersusun dengan baik. Semua kekurangan yang ada akan lebih ditingkatkan lagi untuk kemajuan voli pantai NTB.

Evaluasi input di sini akan menjelaskan tentang aspek-aspek yang terdapat di dalamnya sesuai dengan hasil wawancara/data kualitatif dari responden dan hasil analisis kuantitaif yang dilakukan.

Tabel 10. Hasil Evaluasi Input NTB

\begin{tabular}{|c|c|c|c|}
\hline Aspek & & & Pencapaian \\
\hline Input & Kategori & Rata-rata & Keterangan \\
\hline Pelatih & Baik & 3.279 & $\begin{array}{l}\text { Sudah baik, dengan pengalaman sebagai mantan atlet dan } \\
\text { lisensi kepelatihan. }\end{array}$ \\
\hline Atlet & Baik & 3.188 & Potensi atlet NTB sangat banyak. \\
\hline $\begin{array}{l}\text { Sarana dan } \\
\text { Prasarana }\end{array}$ & Sangat kurang & 2.730 & $\begin{array}{l}\text { Sangat kurang karena hanya ada satu lapangan voli pantai di } \\
\text { NTB. }\end{array}$ \\
\hline Pendanaan & Sangat kurang & 2.731 & Masih kurang sesuai dengan data yang diambil. \\
\hline Dukungan Ortu & Baik & 3.270 & Dukungan yang positif untuk kemajuan voli pantai NTB. \\
\hline
\end{tabular}

(Sumber Data: Wawancara, Angket, Observasi dan Dokumentasi) 
Jurnal Keolahragaan 5 (1), April 2017 - 33

Johan Irmansyah

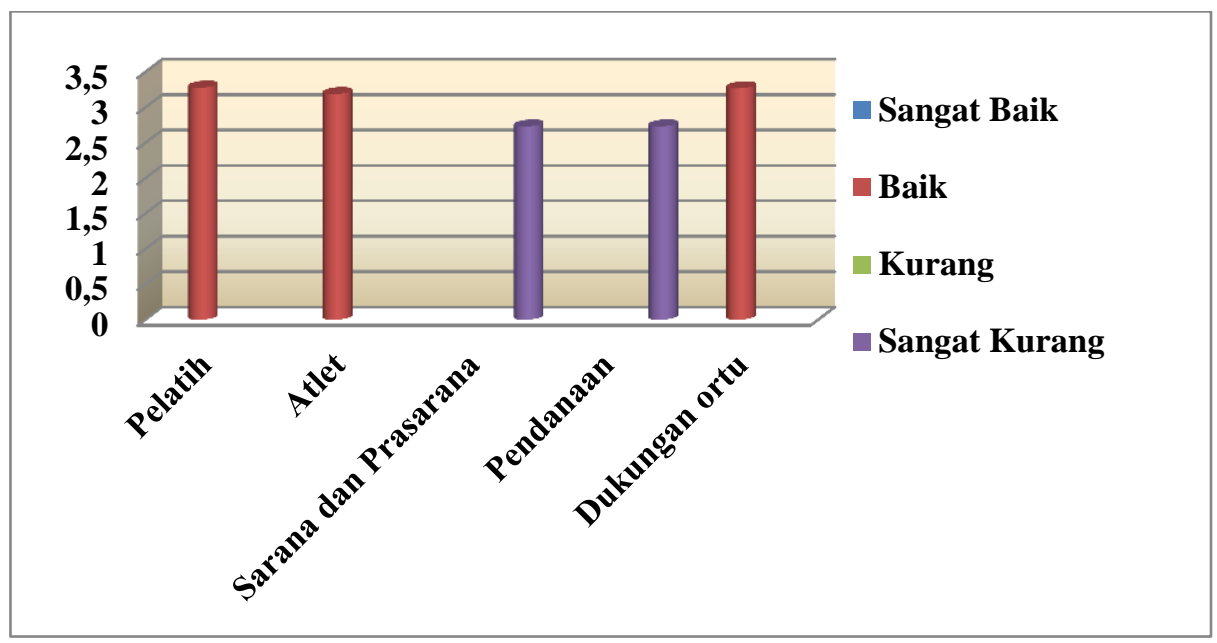

Gambar 6. Histogram Evaluasi Input NTB

Tabel 11. Hasil Evaluasi Process NTB

\begin{tabular}{|c|c|c|c|}
\hline Aspek & & & Pencapaian \\
\hline Process & Kategori & Rata-rata & Keterangan \\
\hline $\begin{array}{l}\text { Pelaksanaan program } \\
\text { latihan }\end{array}$ & Baik & 3.198 & $\begin{array}{l}\text { Sudah berjalan dengan baik di bawah kepemimpinan } \\
\text { pelatih-pelatih yang berkualitas. }\end{array}$ \\
\hline $\begin{array}{l}\text { Pelaksanaan program } \\
\text { pembinaan }\end{array}$ & Sangat kurang & 2.694 & $\begin{array}{l}\text { Masih sangat kurang karena banyaknya masalah internal } \\
\text { di daerah NTB. }\end{array}$ \\
\hline Monev & Sangat kurang & 2.878 & $\begin{array}{l}\text { Masih sangat kuran kompetisi lokal untuk mencari bibit- } \\
\text { bibit baru. }\end{array}$ \\
\hline
\end{tabular}

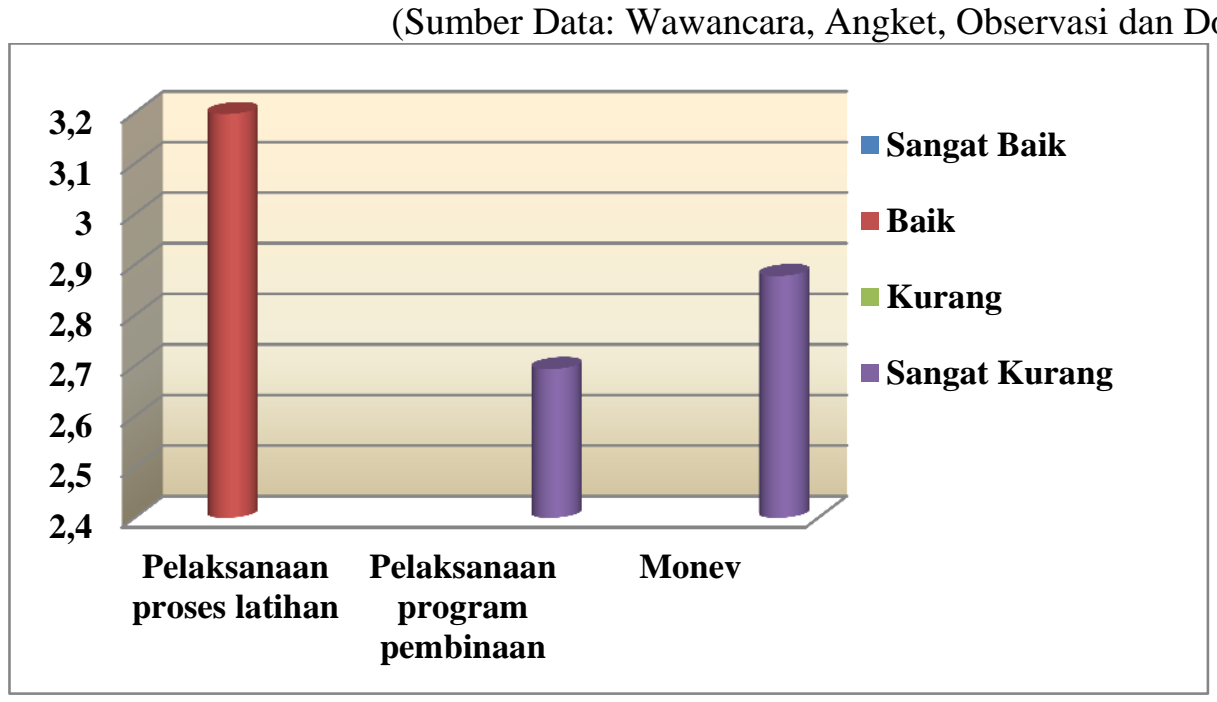

Gambar 7. Histogram Evaluasi Process NTB

Berdasarkan Tabel 10, terdapat banyak sekali permasalahan baik dari pengurus, pelatih dan atlet. Begitu juga dengan keluhan dari orang tua atlet, pelatih, dan atlet itu sendiri tentang masalah sarana dan prasarana masih sangat kurang. Sesuai dengan data yang didapat di lapangan, di NTB masih belum ada sinergi yang baik antara semua orang yang bersangkutan dalam program pembinaan ini, ada masalahmasalah internal yang dibawa ke dalam program pembinaan. Dengan banyaknya masalah yang ada, semua pelatih dan atlet di NTB memiliki motivasi lebih untuk mencapai prestasi maksimal, semua itu dilakukan sebagai pembuktian bahwa cabang olahraga voli pantai perlu diperhatikan dengan serius.

Proses dalam evaluasi ini mencakup aspek-aspek tentang berjalannya pelaksanaan program latihan, pelaksanaan program pembinaan, dan monev dari pengurus PBVSI. Berikut pendapat para responden tentang aspek-aspek yang terdapat di dalam evaluasi process.

Berdasarkan Tabel 11, dapat disimpulkan bahwa pelaksanaan program pembinaan dan 
monev masih sangat kurang, dikarenakan faktorfaktor internal daerah maupun perhatian pemerintah pusat yang masih kurang untuk voli pantai daerah NTB. Untuk pelaksanaan proses latihan sudah berjalan dengan baik, karena berada di bawah pimpinan pelatih-pelatih yang berkualitas di bidang voli pantai.

Evaluasi product membahas tentang prestasi yang telah diraih atlet, baik dari tingkat daerah sampai ke tingkat internasional. Prestasi merupakan tolok ukur keberhasilan suatu program pembinaan yang telah dijalankan oleh tiaptiap provinsi. Berbeda dengan di NTB, meskipun program pembinaan di NTB masih kurang, NTB selalu menghasilkan atlet-atlet terbaik di cabang olahraga voli pantai, bisa dilihat dari prestasi-prestasi yang telah diraih.

Berdasarkan Tabel 12, prestasi atlet NTB secara keseluruhan sudah dalam kategori baik. Semua itu dapat dibuktikan dengan masih ba- nyak atlet NTB yang mampu bersaing di tingkat nasional. NTB juga merupakan salah satu provinsi penghasil atlet-atlet nasional dalam cabang olahraga voli pantai. Dibalik program pembinaan yang masih kurang teratur dan masalah-masalah yang dihadapi, pelatih dan atlet-atlet NTB masih konsisten untuk terus menghasilkan prestasi maksimal.

Setelah dilakukan analisis dari semua aspek yang ada di dalam metode CIPP di DIY dan NTB, peneliti akan memberikan perbandingan hasil evaluasi setiap aspek yang diungkap secara keseluruhan antara DIY dan NTB. Perbandingan hasil evaluasi dari model CIPP dan perbandingan secara keseluruhan dari DIY dan NTB, peneliti juga akan memberikan penjelasaan tentang perbedaan program yang ditemukan serta masalah-masalah yang dihadapi sehingga bisa muncul perbedaan-perbedaan itu.

Tabel 12. Hasil Evaluasi Product NTB

\begin{tabular}{cccc}
\hline Aspek & & & \multicolumn{2}{c}{ Pencapaian } \\
\hline Product & Kategori & Rata-rata & Keterangan \\
\hline Prestasi & BAIK & 3.146 & Hasil prestasi atlet sudah baik, bisa dilihat dalam tabel lampiran \\
\hline
\end{tabular}

(Sumber Data: Angket dan Dokumentasi)

Tabel 13. Perbandingan Hasil Evaluasi Program Pembinaan Prestasi Setiap Aspek yang Diungkap di DIY dan NTB

\begin{tabular}{|c|c|c|c|c|c|}
\hline \multicolumn{6}{|c|}{ Perbandingan Hasil Evaluasi } \\
\hline DI Yogyakarta & Rata-rata & Kategori & Kategori & Rata-rata & NTB \\
\hline Aspek & & & & & Aspek \\
\hline Contexs & & & & & Contexs \\
\hline $\begin{array}{l}\text { Latar belakang program } \\
\text { pembinaan }\end{array}$ & 3.142 & Baik & Baik & 3.264 & $\begin{array}{l}\text { Latar belakang program } \\
\text { pembinaan }\end{array}$ \\
\hline Tujuan program pembinaan & 3.263 & Baik & Baik & 3.167 & Tujuan program pembinaan \\
\hline $\begin{array}{l}\text { Program pembinaan } \\
\text { INPUT }\end{array}$ & 3.263 & Baik & Baik & 3.174 & $\begin{array}{l}\text { Program pembinaan } \\
\text { INPUT }\end{array}$ \\
\hline Pelatih & 3.226 & Baik & Baik & 3.279 & Pelatih \\
\hline Atlet & 3.158 & Baik & Baik & 3.188 & Atlet \\
\hline Sarana dan Prasarana & 3.147 & Baik & $\begin{array}{l}\text { Sangat } \\
\text { kurang }\end{array}$ & 2.730 & Sarana dan Prasarana \\
\hline Pendanaan & 3.168 & Baik & $\begin{array}{l}\text { Sangat } \\
\text { kurang }\end{array}$ & 2.731 & Pendanaan \\
\hline Dukungan ortu & 3.379 & $\begin{array}{l}\text { Sangat } \\
\text { baik }\end{array}$ & Baik & 3.270 & Dukungan ortu \\
\hline PROCESS & & & & & PROCESS \\
\hline Pelaksanaan proses latihan & 3.151 & Baik & Baik & 3.198 & Pelaksanaan proses latihan \\
\hline $\begin{array}{l}\text { Pelaksanaan program } \\
\text { pembinaan }\end{array}$ & 3.183 & Baik & $\begin{array}{l}\text { Sangat } \\
\text { kurang }\end{array}$ & 2.694 & $\begin{array}{l}\text { Pelaksanaan program } \\
\text { pembinaan }\end{array}$ \\
\hline Monev & 3.443 & $\begin{array}{c}\text { Sangat } \\
\text { baik }\end{array}$ & $\begin{array}{l}\text { Sangat } \\
\text { kurang }\end{array}$ & 2.878 & Monev \\
\hline $\begin{array}{l}\text { PRODUCT } \\
\text { Prestasi }\end{array}$ & & & & & PRODUCT \\
\hline Prestasi & 3.153 & Baik & Baik & 3.146 & \\
\hline
\end{tabular}

(Sumber Data: Wawancara, Angket, Observasi, dan Dokumentasi) 
Jurnal Keolahragaan 5 (1), April 2017 - 35

Johan Irmansyah

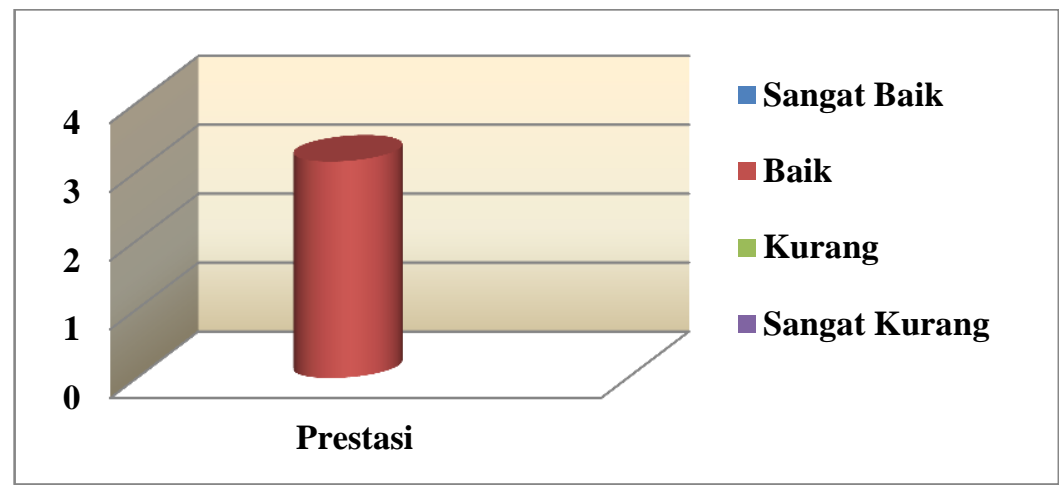

Gambar 8. Histogram Evaluasi Product NTB

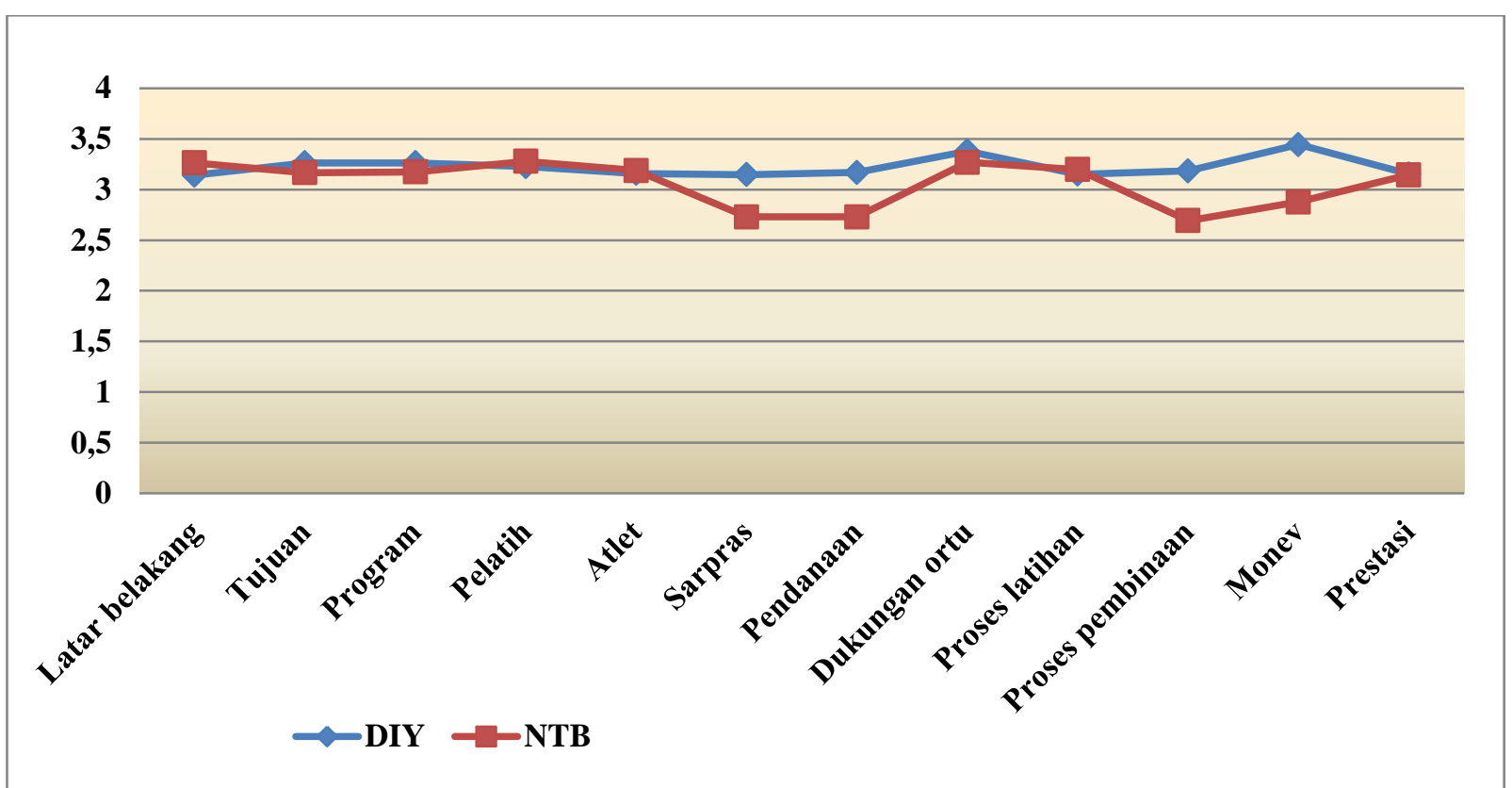

Gambar 9. Perbandingan Hasil Evaluasi Setiap Aspek yang Diungkap di DIY dan NTB

Tabel 14. Perbandingan Hasil Evaluasi Program Pembinaan Prestasi dari Model CIPP di DIY dan NTB

\begin{tabular}{cccccc}
\hline \multicolumn{5}{c}{ Perbandingan Hasil Evaluasi } \\
\hline Yogyakarta & Rata-rata & Kategori & Kategori & Rata-rata & Ntb \\
\hline Aspek & & & & Aspek \\
\hline Contexs & 3.222222222 & Baik & Baik & 3.201388889 & Contexs \\
Input & 3.21563212 & Baik & Kurang & 3.039667108 & Input \\
Process & 3.259215686 & Sangat baik & Sangat kurang & 2.923240741 & Process \\
Product & 3.152941176 & Baik & Baik & 3.146296296 & Product \\
\hline
\end{tabular}

(Sumber Data: Wawancara, Angket, Observasi dan Dokumentasi)

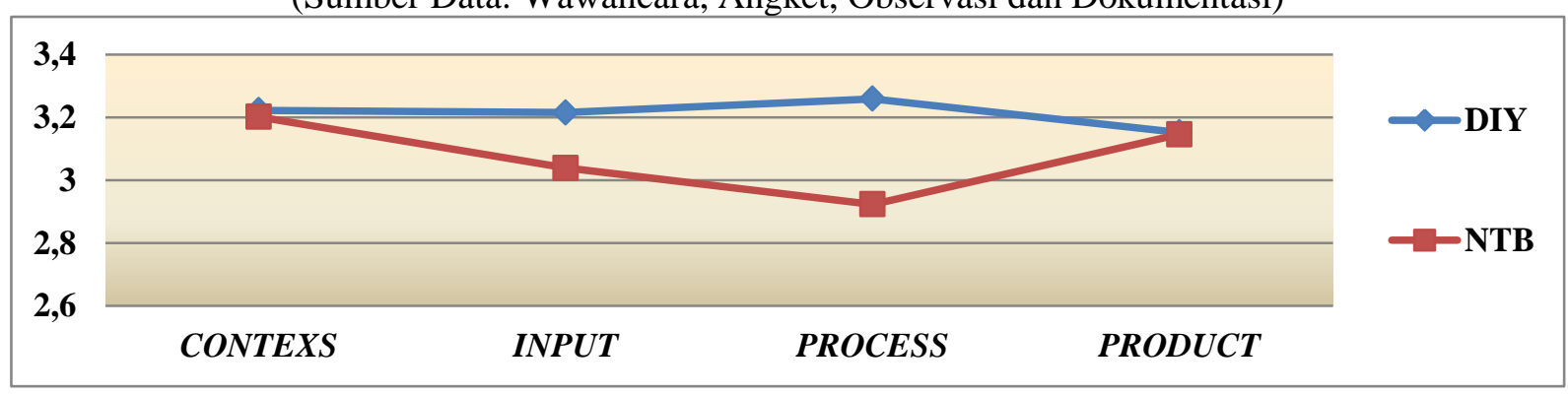

Gambar 10. Perbandingan Hasil Evaluasi Model CIPP DIY dan NTB 
Jurnal Keolahragaan 5 (1), April 2017 - 36

Johan Irmansyah

Tabel 15. Perbandingan Hasil Evaluasi Program Pembinaan Prestasi di DIY dan NTB

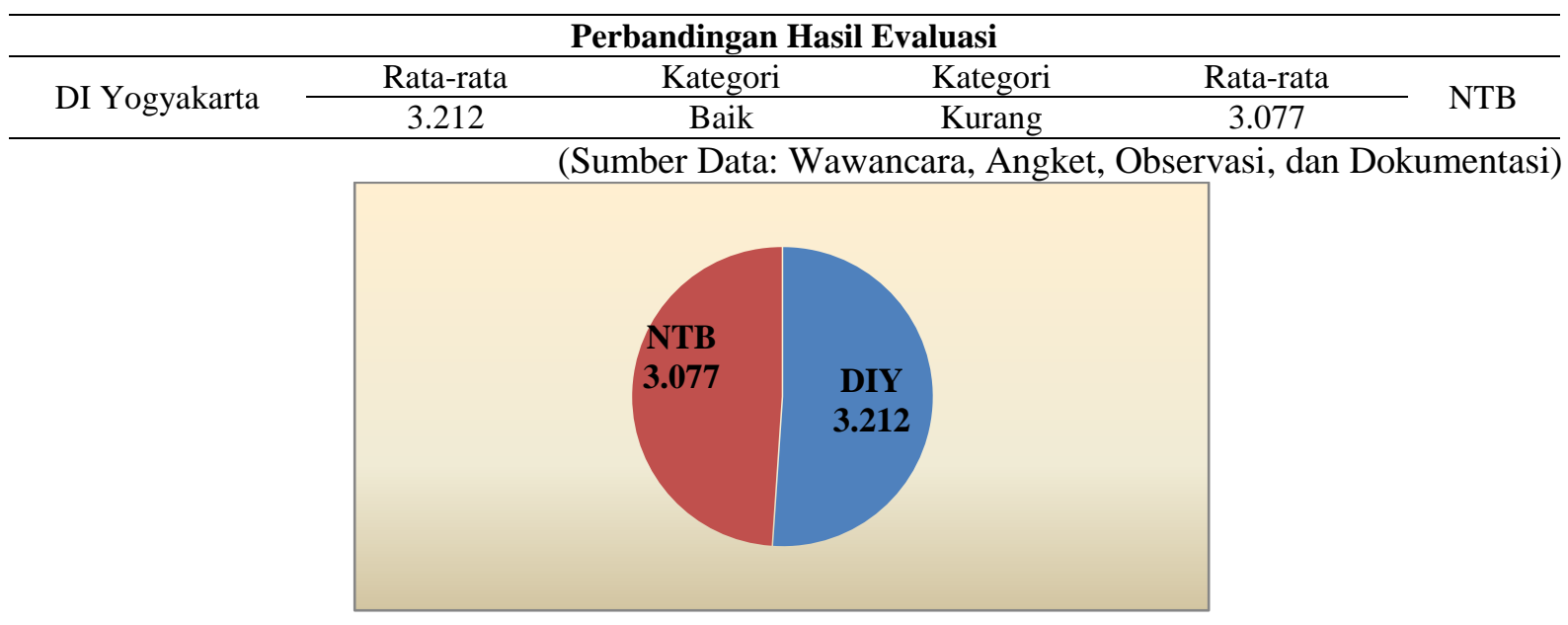

Gambar 11. Diagram Pie Perbandingan di DIY dan NTB

Berdasarkan Tabel 14, hasil perbandingan setiap aspek yang diungkap dalam evaluasi program pembinaan prestasi voli pantai di DIY dan NTB dapat dilihat bahwa kedua provinsi ini memiliki perbedaan yang sangat signifikan dalam program pembinaan yang dijalankan. DIY dengan program pembinaan yang sudah berjalan dengan baik dan NTB dengan program pembinaan yang masih mengalami banyak masalah yang belum mampu terselesaikan. Point penting adalah DIY dan NTB merupakan provinsi yang selalu menghasilkan atlet-atlet voli pantai terbaik di Indonesia. Selanjutnya akan dijelaskan perbandingan hasil evaluasi program pembinaan prestasi dari model CIPP di DIY dan NTB.

Perbandingan hasil evaluasi model CIPP DIY dan NTB di atas semakin menjelaskan bahwa program pembinaan prestasi voli pantai di NTB harus segera dibenahi. Kondisi ini dapat memengaruhi mental atlet-atlet yang sudah berlatih dengan keras dan profesional untuk kemajuan voli pantai NTB. Hal ini juga tidak menutup kemungkinan prestasi voli pantai NTB akan menurun jika dalam program pembinaannya saja sudah tidak baik. Penjelasan selanjutnya tentang perbandingan secara keseluruhan hasil evaluasi program pembinaan prestasi voli pantai di DIY dan NTB.

Berdasarkan Tabel 15, hasil data analisis evaluasi program pembinaan di DIY dan NTB di atas, dapat ditarik kesimpulan bahwa terdapat banyak sekali perbedaan antara program pembinaan voli pantai di DIY dan NTB. Kedua provinsi ini memiliki perbedaan yang sangat signifikan jika dilihat berdasarkan data analisis tersebut. Yang menjadi sorotan utama adalah masalah sarana dan prasarana, pendanaan, pelaksanaan program pembinaan, dan monev yang ada di NTB. Jika membahas pelaksanaan program pembinaan di NTB, peneliti menemukan fakta-fakta di lapangan bahwa hubungan antara pengurus dan atlet maupun pengurus dengan pelatih masih kurang baik. Masih ada kesenjangan pemikiran yang membuat semua program tidak berjalan sesuai dengan rencana. Untuk masalah sarana dan prasarana di NTB, peneliti merasa prihatin karena untuk level voli pantai NTB yang sudah banyak menghasilkan atlet-atlet nasional hanya memiliki satu lapangan voli pantai dan itu pun atlet laki-laki dan atlet perempuan latihannya masih digabung dengan satu net. Masalah pendanaan di NTB yang dirasa masih minim oleh beberapa responden yang diteliti, dana yang disediakan untuk cabang olahraga voli pantai masih dirasakan tidak sesuai dengan prestasi-prestasi yang dihasilkan selama ini. Pemprov daerah dan pemerintah pusat seharusnya lebih menekankan perhatiannya terhadap cabang olahraga voli pantai di NTB. Dengan banyaknya masalah-masalah internal yang dihadapi di NTB, atlet-atletnya masih mampu mengukir prestasi tinggi di tingkat nasional maupun international. Semua itu dikarenakan adanya orang-orang hebat yang mau mengorbankan waktu, tenaga, pikiran, bahkan dananya sendiri untuk eksistensi voli pantai NTB di kancah international, yaitu kepala pelatih voli pantai NTB Agus Salim dan para pelatih lainnya. Oleh karena itu, prestasi bukan hanya bisa dihasilkan dari program pembinaan yang baik, melainkan visi dan misi dari para pelatih hebat yang memiliki kemampuan dan loyalitas tinggi dalam memajukan voli pantai NTB.

Berbanding terbalik dengan program pembinaan di DIY yang telah tersusun dengan 
baik dan pelaksanaannya juga telah berjalan sesuai dengan prosedur yang ditentukan, salah satu contoh program PRIMA PRATAMA yang difokuskan pembibitan atlet dari usia dini dan diberikan fasilitas sesuai dengan kebutuhan atlet. DIY juga merupakan salah satu provinsi di Indonesia yang selalu menghasilkan atlet-atlet berprestasi di cabang olahraga voli pantai, selain karena program pembinaannya yang sudah baik, DIY juga memiliki orang-orang hebat dengan visi dan misi yang sangat brilian dalam memajukan voli pantai DIY, sebut saja Koko Prasetyo, beliau adalah salah satu atlet terbaik DIY dan Indonesia yang masih mensejajarkan eksistensinya di kancah voli pantai international, ditambah dengan para pengurus voli pantai DIY yang selalu memonitoring dan mengevaluasi kekurangan-kekurangan yang ada untuk kemajuan voli pantai DIY. Oleh karena itu, dengan program pembinaan yang baik, orang-orang yang berkompeten dan potensi atlet yang berkualitas menjadikan DIY salah satu provinsi terbaik penghasil atlet-atlet voli pantai nasional.

\section{SIMPULAN, IMPLIKASI, DAN SARAN}

\section{Simpulan}

Evaluasi secara keseluruhan menurut model CIPP di NTB menunjukkan bahwa masih banyak kekurangan dalam program pembinaan prestasi voli pantai di NTB, mulai dari sarana dan prasarana, pendanaan, pelaksanaan program pembinaan dan monev. Evaluasi program pembinaan prestasi voli pantai secara keseluruhan menurut model CIPP di DIY sudah berjalan dengan baik, baik dari program pembinaan sampai dengan prestasi yang dihasilkan. Evaluasi program pembinaan prestasi ditinjau dari segi contexs yang ada DIY dan NTB sudah terlaksana dengan baik, dari semua aspek yang telah diungkap menunjukkan hasil yang positif dari kedua provinsi tersebut.

\section{Evaluasi Input}

Evaluasi program pembinaan prestasi ditinjau dari segi input, hasil analisis dan evaluasi program pembinaan di atas menjelaskan perbedaan yang sangat signifikan antara DIY dan NTB, yaitu masalah sarana dan prasarana maupun pendanaan. Masih sangat kurang perhatian pemerintah daerah di NTB tentang pendanaan dan sarana prasarana, berbanding terbalik dengan kondisi yang ada di DIY yang telah memiliki fasilitas cukup lengkap dalam cabang olahraga voli pantai.

\section{Evaluasi Process}

Evaluasi program pembinaan prestasi ditinjau dari process yang dijalankan DIY dan NTB sudah terlaksana sesuai dengan prosedur, namun berdasarkan hasil analisis dan evaluasi tersebut, ditemukan fakta bahwa pelaksanaan program pembinaan dan monev di NTB masih sangat kurang. Itu berarti semua hal yang telah disusun dalam program pembinaan belum terlaksana dengan maksimal. Kekurangan-kekurangan itu yang menjadi bahan evaluasi untuk meningkatkan kinerja dalam program pembinaan voli pantai di NTB.

\section{Evaluasi Product}

Evaluasi program pembinaan prestasi ditinjau dari segi product di DIY dan NTB menunjukkan bahwa provinsi DIY dan NTB telah memiliki prestasi yang baik dalam cabang olahraga voli pantai. Ini dapat dilihat dari hasil dokumentasi dan wawancara yang didapat oleh peneliti.

\section{Implikasi}

Implikasi dari hasil analisis dan evaluasi ini diharapkan dapat menjadi bahan acuan untuk memperbaiki kekurangan-kekurangan yang ada dalam program pembinaan voli pantai di DIY dan NTB. Oleh karena itu sangat perlu dilakukan evaluasi untuk meningkatkan kinerja dalam penyusunan dan pelaksanaan program pembinaan prestasi. Selain itu diharapkan hubungan antara pengurus, pelatih, atlet dan orang tua bisa terjalin lebih baik lagi dan mampu bekerja sama untuk kemajuan program pembinaan serta prestasi di level yang lebih tinggi lagi.

\section{Saran}

Berdasarkan data analisis dan hasil evaluasi program pembinaan prestasi di DIY dan NTB, dapat diajukan enam saran/rekomendasi sebagai berikut: (1) Pemprov NTB harus memberikan konstribusi yang lebih maksimal terutama dalam hal pendanaan dan sarana prasarana demi tercapainya prestasi yang diharapkan; (2) Pengurus PBVSI NTB harus memperbaiki pelaksanaan program pembinaan yang masih sangat kurang beserta meningkatkan lagi kinerja dalam melakukan monev (monitoring dan evaluasi); (3) Pengurus PBVSI DIY dan NTB harus lebih banyak melakukan kompetisi-kompetisi lokal, dengan begitu akan muncul bibit-bibit atlet voli pantai yang baru; (4) Rekruitmen atlet di DIY dan NTB harus dilakukan sesuai dengan prosedur yang telah ditetapkan, tidak disarankan 
Johan Irmansyah

untuk memilih atlet secara subjektif; (5) Hubungan antara pengurus, pelatih, atlet dan orang tua di DIY dan NTB bisa terjalin lebih baik lagi dan mampu bekerja sama untuk kemajuan program pembinaan serta prestasi di level yang lebih tinggi lagi; (6) Pelaksanaan program latihan harus dilakukan dengan serius, terutama untuk atlet diharapkan selalu fokus dan bersikap professional jika ingin mencapai level prestasi terbaik.

\section{DAFTAR PUSTAKA}

Arikunto, S., \& Jabar, C. S. A. (2009). Evaluasi program pendidikan (2nd ed.). Jakarta: Bumi Aksara.

Farquhar, M. C., Ewing, G., \& Booth, S. (2011). Using mixed methods to develop and evaluate complex interventions in palliative care research. Palliative Medicine, 25(8), 748-757. http://doi.org/10.1177/0269216311417919
Gall, M. D., Gall, J. P., \& Borg, W. R. (2007). Educational research: An introduction. Pearson/Allyn \& Bacon.

Harsuki, H. (2012). Pengantar manajemen olahraga. Jakarta: PT Raja Grafindo Persada.

Mutohir, T. C., \& Maksum, A. (2007). Sport development index, alternatif baru mengukur kemajuan pembangunan bidang keolahragaan. Jakarta: PT Indeks.

Sugiyono. (2004). Metode penelitian kombinasi (Mixed method). Bandung: CV Alfabeta. Bandung: CV Alfabeta.

Widoyoko, E. P. (2012). Teknik penyusunan instrumen penelitian. Yogyakarta: Pustaka Pelajar.

Worthen, B. R., Sanders, J. R., \& Fitzpatrick, J. L. (2004). Program evaluation: Alternative approaches and practical guidelines (3rd ed.). Boston: Allyn and Bacon. 